\title{
Quality of life indicators in selected European countries: Hierarchical cluster analysis approach
}

\author{
Berislav Žmuk \\ Faculty of Economics and Business, University of Zagreb, Zagreb, Croatia \\ bzmuk@efzg.hr
}

\begin{abstract}
The average expected duration of human life is rising because of different reasons. On the other hand, not only the duration, but the quality of life level is important, too. The higher the quality of life level, the citizens' happiness and satisfaction levels are higher, which has positive impact on the development and operating of an economy. The goal of this paper is to identify groups of European countries, using statistical hierarchical cluster analysis, by using the quality of life indicators, and to recognise differences in quality of life levels. The quality of life is measured by using seven different indicators. The conducted statistical hierarchical cluster analysis is based on the Ward's clustering method, and squared Euclidean distances. The results of conducted statistical hierarchical cluster analysis enabled recognizing of three different groups of European countries: old European Union member states, new European Union members, and non-European Union member states. The analysis has revealed that the old European Union member states seem to have in average higher quality of life level than the new European Union member states. Furthermore, the European Union member states have in average higher quality of live level than non-European Union members do. The results indicate that quality of life levels and economic development levels are connected.
\end{abstract}

Keywords: quality of life indicators, Ward's method, outlier detection, European countries, analysis of variance (ANOVA).

JEL classification: C12, C38, D60, 130.

DOI: 10.1515/crebss-2016-0004

Received: October 1, 2015

Accepted: December 1, 2015

\section{Introduction}

The quality of life variables started to be officially observed in the sixties and early seventies of the 20th century (Noll, 2004). Since then many scientist at different institutions have been observing the quality of life level using variety of different indicators. Usage of many indicators to describe one composite phenomenon, such as the quality of life, illustrates the complexity and issues in setting unique definition of what quality of life is. This problem is present at both, countries and local levels, too (Greenwood, 2001). 
According to Diener and Suh (1997), researchers usually used social indicators, subjective well-being measures and economic indices to define and measure quality of life. These indicators are based on three different philosophical approaches and because of that, each group of indicators has information that is not contained in another one. The first approach describes characteristics of the quality life that are dictated by normative ideals, the second approach is based on the satisfaction of preferences, whereas the third approach takes into account of the experience of individuals (Constanza et al., 2007). Of course, each group of indicators has some strengths and weaknesses. Due to use of different approaches, the comparability of quality of life levels between them is very low.

Eurostat is monitoring the quality of life using nine following "dimensions" such as: material living conditions; productive or main activity; health; education; leisure and social interactions; economic and physical safety; governance and basic rights; natural and living environment; and overall experience of life (Eurostat, 2015). Each of these "dimensions" is consisted of selected relevant statistical indicators. On the other side, OECD describes the quality of life as the set of non-monetary attributes of individuals, their opportunities and life chances. Furthermore, according to OECD the quality of life has intrinsic value under different cultures and contexts (OECD, 2011). OECD observes quality of life using 11 "dimensions": housing; income and wealth; jobs and earnings; social connections; education and skills; environmental quality; civic engagement and government; health status; subjective well-being; personal security; and work and life.

As opposite to Eurostat and OECD, Economist Intelligence Unit uses only nine indicators to describe the quality of life: material wellbeing; health; political stability and security; family life; community life; climate and geography; job security; political freedom; and gender equality (Economist Intelligence Unit, 2004). For the sake of standardization and increased comparability, the simpler approach to quality of life by using smaller number of carefully selected indicators instead of using many of them is preferred (Tonon, 2015). Therefore, in this paper only seven carefully selected underived quality of life indicators are used.

In the quality of life analysis, the method of statistical clustering is often used. Krupka et al. (2013) observed quality of life problem in 17 member states of European Monetary Union. By using cluster analysis, they have recognized countries with high, average and low standards of living. Grein, Sethi and Tatum (2010) used cluster analysis in order to reduce the complexity and to explore relationships between countries. In the research, except quality of life variables, they used economic, technological, cultural and demographic variables, also. Hirschberg, Maasoumi, and Slottje (1991) used different statistical cluster analysis methods to explore different ways and levels for clustering of 23 diverse variables, which can be used to describe quality of life in a country. The conclusions from that study the same authors, Hirschberg, Maasoumi, and Slottje (2001) observed quality of life in the United States of America by using statistical clustering approach, too. The statistical clustering is especially often applied when quality of life is observed in the health research (Nagel et al., 2001, Hayashi et al., 2011, Pakran, Riyaz, Nandakumar, 2011).

The aim of this paper is to inspect quality of life levels in European countries and to compare the achieved quality of life levels between the observed countries. The European Union is thought to be union of high-developed countries because of strict criteria, which a country must fulfil in order to join the union (see i.e. European Commission, 2015). Furthermore, the European Union member states are often divided on the "old", which joined the European Union before 2000, and on the "new" ones, which joined the European Union after the 2000 (Toshkov et al., 2014). 
So, the research question is, are there some differences in quality of life levels between the old and the new European Union member states or not. In addition, it is a question, are there some differences in quality of life levels when the European Union member states and other European countries, which are outside of the European Union, are compared. Consequently, the following research hypotheses are formed:

$\mathrm{H}_{1} \ldots$ The old European Union member states have in average higher quality of life level than the new European Union member states.

$\mathrm{H}_{2} \ldots$ The European Union member states have in average higher quality of live level than non-European Union member states.

After brief introduction, data and methods used are described in the chapter 2. In the chapter 3 , descriptive analysis and outlier detection of seven selected quality of life indicators are conducted. According to selected quality of life indicators, 34 European countries are clustered using statistical hierarchical cluster analysis in the chapter 4. The comparison of quality of life levels between old, new and nonEuropean Union member states is conducted.

\section{Data and methods}

The quality of life should be examined by observing different variables that cover all aspects of life, having significant impact on its quality. Therefore, here are allocated overall seven variables or quality of life indicators, and these are: the Purchasing Power Index, the Safety Index, the Health Care Index, the Consumer Price Index, the Property Price to Income Ratio, the Traffic Commute Time Index, and the Pollution Index. All selected variables are objective quality of life indicators, which should ensure high comparability in the future studies (Noll, 2004, Georgiou, Hancock, 2009). In order to select the variables the European Union, the results of Survey on Income and Living Conditions (EU-SILC) was studied (Insee, 2010). Since only objective quality of life indicators were selected, the following four objective quality of life areas were covered: living conditions, economic strain, health, and working conditions. In comparison to EU-SILC, the following three subjective quality of life areas were not covered: social networks, social participation, and education (Smedt, 2015). In Table 1, the list of selected quality of life indicators according covered quality of life areas is given. Despite of the small number of included quality of life indicators, and omitting of subjective quality of life indicators, it is believed that selected variables together will ensure a quite good quality of life level estimation in a country.

Table 1 Selected quality of life indicators and quality of life areas, which they cover

\begin{tabular}{|l|l|}
\hline \multicolumn{1}{|c|}{$\begin{array}{c}\text { Selected quality of life } \\
\text { indicators }\end{array}$} & $\begin{array}{c}\text { Covered quality of life } \\
\text { areas }\end{array}$ \\
\hline Purchasing Power Index & Economic strain \\
\hline Safety Index & Living conditions \\
\hline Health Care Index & Health \\
\hline Consumer Price Index & Economic strain \\
\hline Property Price to Income Ratio & Living conditions \\
\hline Traffic Commute Time Index & Working conditions \\
\hline Pollution Index & Health \\
\hline
\end{tabular}

Source: author.

The Purchasing Power Index gives relative purchasing power of goods and services of residents in a country for the average wage in that city. Originally, this 
measure is given at the city level. Therefore, the used base for indices values comparisons is New York City (Numbeo, 2015a).

The Safety Index is an estimation of overall level of safety in a given country. The Safety Index is standardized on scale from 0 to 100. If the Safety Index is closer to 0 , the residents consider their country very unsafe. On the other side, the high Safety Index values show that observed country is considered to be very safe (Numbeo, 2015b).

The Health Care Index shows the overall quality level of the whole health care systems in a country. The Health Care Index is also standardized into the $[0,100]$ interval. The closer the value of the Health Care Index to 100, the higher the health care system quality level by residents is considered (Numbeo, 2015c).

The Consumer Price Index is a relative indicator of consumer goods price. It includes groceries, restaurants, transportation and utilities, but does not include accommodation expenses. As the Purchasing Power Index, the Consumer Price Index values are also compared to the New York City (Numbeo, 2015a).

The Price to Income Ratio measures the apartment purchase affordability in a country. It takes into account net disposable family income, which is estimated as one and half of an average net salary. In addition, it is assumed that the size of an apartment is 90 square meters, which price per square meter is defined as an average of the apartment price in the city centre and outside of the city centre (Numbeo, 2015e).

The Traffic Commute Time Index shows average one-way time needed commuters to travel from home to the job, or vice versa. The Traffic Commute Time Index is expressed in minutes (Numbeo, 2015f).

The Pollution Index is used to estimate the overall pollution in a country. The Pollution Index includes many pollution types, but the highest weights are given to air and water pollution. Because of easier interpretation, the Pollution Index can have values from 0 to 100. The lower the Pollution Index value, the lower the pollution level is considered (Numbeo, 2015d).

The data for all seven observed quality of life indicators are collected for overall 34 European countries in 2015 (Numbeo, 2015g). The research includes 14 old European Union member states (Austria, Belgium, Denmark, Finland, France, Germany, Greece, Ireland, Italy, Netherlands, Portugal, Spain, Sweden, the United Kingdom), 11 new European Union member states (Bulgaria, Croatia, the Czech Republic, Estonia, Hungary, Latvia, Lithuania, Poland, Romania, Slovakia, Slovenia), and 9 European countries which are not European Union members (Belarus, Bosnia and Herzegovina, the Former Yugoslav Republic of Macedonia (FYROM), Moldova, Norway, Russia, Serbia, Switzerland, Ukraine). Firstly conducted, descriptive statistical analysis includes outliers detection.

According to Jain (2010), the cluster analysis is the formal study of methods and procedures for grouping the objects according to measured intrinsic characteristics or similarity. In this paper, the hierarchical clustering is applied. In the agglomerative hierarchical procedure, all objects are initially put in separate clusters. According to difference size between objects, in the next step(s), they are joined into the new cluster. In the final step, all the objects are in the same cluster. In clustering the Ward's method and the squared Euclidean distances are used (Everitt, Landau, Leese, 2001). After that, the clusters means for each observed variable are calculated with a purpose of comparing the quality of life levels between clusters. 


\section{Descriptive and outlier analysis of selected quality of life indicators}

Each quality of life indicator is focused on only one, often very narrow, quality of area. Consequently, different quality of life indicators lead to different ranking of countries. In other words, using one quality of life indicator a country could be very good placed, and it can be stated that residents in this country have high quality of life level. On the other hand, another quality of life indicator value could lead to conclusion that the same country has low quality of life level. In Table 2, top five European countries with the highest achieved quality of life level according to seven selected quality of life indicators in 2015 are listed.

Table 2 Top five European countries with the highest quality of life level according to selected quality of life indicators in 2015

\begin{tabular}{|c|c|c|c|c|c|}
\hline Variable / Indicator & Rank 1 & Rank 2 & Rank 3 & Rank 4 & Rank 5 \\
\hline $\begin{array}{l}\text { Purchasing Power Index } \\
\text { Safety Index } \\
\text { Health Care Index } \\
\text { Consumer Price Index }\end{array}$ & $\begin{array}{l}\text { Switzerla. } \\
\text { Denmark } \\
\text { France } \\
\text { Moldova }\end{array}$ & $\begin{array}{l}\text { Germany } \\
\text { Austria } \\
\text { Denmark } \\
\text { FYROM }\end{array}$ & $\begin{array}{l}\text { Sweden } \\
\text { Switzerla. } \\
\text { Austria } \\
\text { Ukraine }\end{array}$ & $\begin{array}{l}\text { Denmark } \\
\text { Estonia } \\
\text { Belgium } \\
\text { BlH }\end{array}$ & $\begin{array}{l}\text { Austria } \\
\text { Germany } \\
\text { Sweden } \\
\text { Romania }\end{array}$ \\
\hline $\begin{array}{l}\text { Property Price to Income } \\
\text { Ratio } \\
\text { Traffic Commute Time Index } \\
\text { Pollution Index }\end{array}$ & $\begin{array}{l}\text { Denmark } \\
\text { Slovenia } \\
\text { Finland }\end{array}$ & $\begin{array}{l}\text { Ireland } \\
\text { BIH } \\
\text { Sweden }\end{array}$ & $\begin{array}{l}\text { Netherla. } \\
\text { Estonia } \\
\text { Estonia }\end{array}$ & $\begin{array}{l}\text { Belgium } \\
\text { Latvia } \\
\text { Norway }\end{array}$ & $\begin{array}{l}\text { Germany } \\
\text { Moldova } \\
\text { Switzerla. }\end{array}$ \\
\hline
\end{tabular}

Source: author.

Country rankings, given in Table 1, confirmed that each quality of life indicator different ranks countries according their quality of life level. Still, it can be noticed that some countries are appearing more often in the top five ranking than the others. The most number of ranking in top five European countries according to the quality of life indicators has Denmark, which appeared there four times. Austria, Estonia, Germany, Sweden and Switzerland have been ranked three times in the top five European countries according to observed quality of life indicators.

Table 3 Top five European countries with the lowest quality of life level according to selected quality of life indicators in 2015

\begin{tabular}{|c|c|c|c|c|c|}
\hline Variable / Indicator & Rank 1 & Rank 2 & Rank 3 & Rank 4 & Rank 5 \\
\hline $\begin{array}{l}\text { Purchasing Power Index } \\
\text { Safety Index } \\
\text { Health Care Index } \\
\text { Consumer Price Index }\end{array}$ & $\begin{array}{l}\text { Moldova } \\
\text { Russia } \\
\text { FYROM } \\
\text { Switzerla. }\end{array}$ & $\begin{array}{l}\text { Ukraine } \\
\text { France } \\
\text { Ukraine } \\
\text { Norway }\end{array}$ & $\begin{array}{l}\text { FYROM } \\
\text { Moldova } \\
\text { Belarus } \\
\text { Denmark }\end{array}$ & $\begin{array}{l}\text { Belarus } \\
\text { Ukraine } \\
\text { Romania } \\
\text { UK }\end{array}$ & \begin{tabular}{|l} 
Russia \\
Ireland \\
Ireland \\
Ireland
\end{tabular} \\
\hline $\begin{array}{l}\text { Property Price to Income } \\
\text { Ratio }\end{array}$ & Ukraine & Moldova & Serbia & Belarus & FYROM \\
\hline $\begin{array}{l}\text { Traffic Commute Time Index } \\
\text { Pollution Index }\end{array}$ & $\begin{array}{l}\text { Russia } \\
\text { FYROM }\end{array}$ & $\begin{array}{l}\text { Ukraine } \\
\text { Russia }\end{array}$ & $\begin{array}{l}\text { Italy } \\
\text { Ukraine }\end{array}$ & $\begin{array}{l}\text { Netherla. } \\
\text { Bulgaria }\end{array}$ & $\begin{array}{l}\text { Poland } \\
\text { BIH }\end{array}$ \\
\hline
\end{tabular}

Source: author.

According to Table 2, the top five positions are mostly occupied from the Northern and Western European countries. On the other hand, Table 3 reveals that the last five positions, according to values of selected quality of life indicators in 2015, are usually held by the Eastern European countries. At six of seven observed quality of life indicators Ukraine was placed on one of five last positions. According to observed quality of life indicators, the values for Russia and the Former Yugoslav Republic of 
Macedonia (FYROM) were placed four times at one of five last positions. It has to be emphasized that in Table 2 the countries are ranked from the highest quality of life level to the lower one. In Table 3, countries are ranked from the lowest quality of life level to the higher one.

Table 4 Basic descriptive statistics of selected quality of life indicators in $2015, n=34$ European countries

\begin{tabular}{|l|r|r|r|r|r|r|}
\hline \multirow{2}{*}{\multicolumn{1}{c|}{ Variable / Indicator }} & \multicolumn{7}{|c|}{ Statistics } \\
\cline { 2 - 7 } & Mean & $\begin{array}{c}\text { Stand. } \\
\text { dev. }\end{array}$ & $\begin{array}{c}\text { Coeff. } \\
\text { of var. }\end{array}$ & Median & \multicolumn{1}{c|}{ Min } & Max \\
\hline Purchasing Power Index & 68.70 & 30.42 & 44.28 & 60.86 & 23.70 & 146.51 \\
Safety Index & 62.73 & 7.95 & 12.67 & 64.05 & 48.67 & 74.29 \\
Health Care Index & 62.63 & 12.02 & 19.19 & 65.70 & 35.12 & 82.58 \\
Consumer Price Index & 66.98 & 23.40 & 34.94 & 61.56 & 34.72 & 126.03 \\
Property Price to Income Ratio & 10.55 & 3.39 & 32.18 & 9.69 & 5.02 & 17.38 \\
Traffic Commute Time Index & 30.07 & 5.39 & 17.91 & 30.45 & 18.82 & 47.08 \\
Pollution Index & 42.57 & 16.60 & 39.00 & 44.15 & 14.91 & 82.31 \\
\hline
\end{tabular}

Source: author.

Table 4 shows basic descriptive statistics results for each of seven observed quality of life indicators in 34 European countries in 2015. The coefficient of variation for the Purchasing Power Index shows the highest differences in quality of life among the observed countries. High level of data variation is also present at Pollution Index, Consumer Price Index and at Property Price to Income Ratio. Observed quality of life indicators use different metrics and are given in different measures. Because of that, the direct comparison between the quality of life indicators cannot be done. Therefore, all data at each quality of life indicator are standardized. Figure 1 shows the multiple Box-Plot based on respected z-scores.

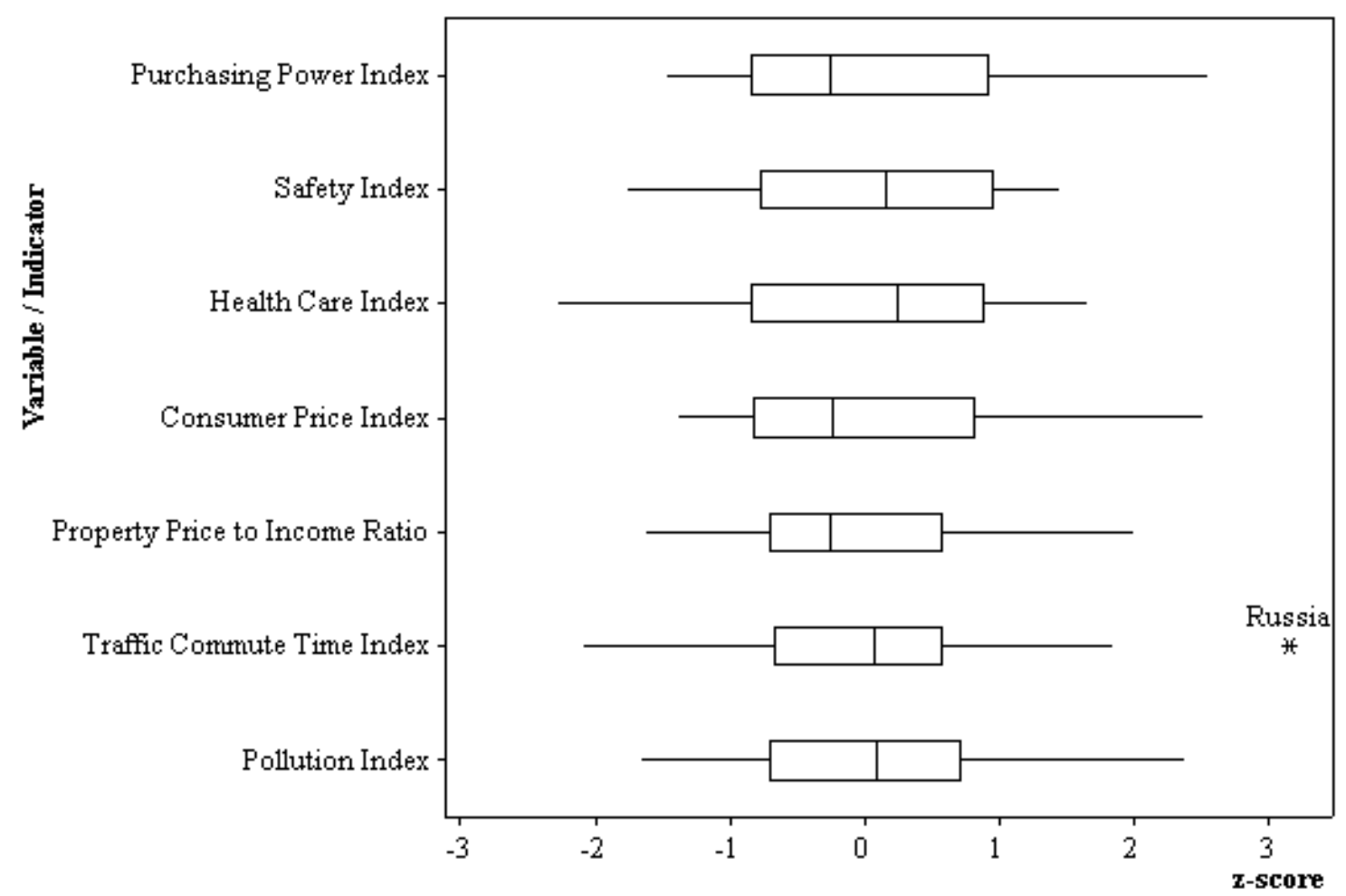

Figure 1 Box-Plots of selected quality of life indicators, standardized values, in 2015 , n=34 European countries

Source: author. 
Box-Plots, given in Figure 1, have shown that there only one data may be considered as an outlier. According to the Traffic Commute Time Index commuters in Russia in average spent 47.08 minutes in one way commuting. That is 3.16 standard deviations more than the average one way commuting time is in observed 34 European countries. This result suggests that Russia should be omitted from the further analysis. Still, it has been estimated that this outlier should not have serious impact on the results of the further analysis. Because of that, it has been decided not to omit Russia.

\section{Hierarchical cluster analysis of selected European countries using selected quality of life indicators}

In order to group countries according to theirs quality of life levels, the statistical hierarchical cluster analysis approach is used. The analysis was performed using the standardized values of all seven observed quality of life indicators, the Ward's linkage, and the squared Euclidean distances.

The dendrogram of conducted hierarchical cluster analysis is shown in Figure 2, whereas the members list of each cluster is given in Table 5.

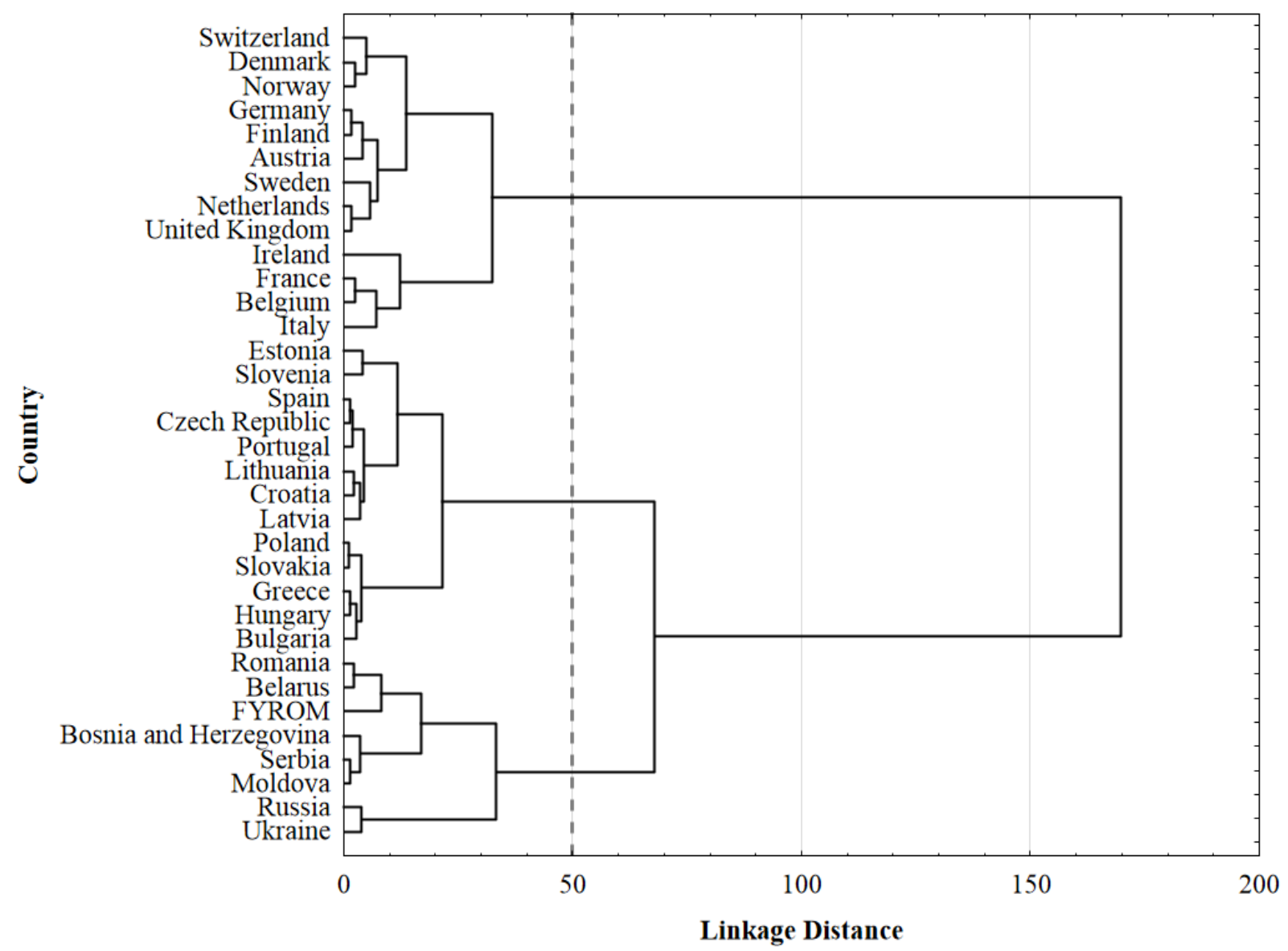

Figure 2 Dendrogram of 34 European countries clustered according to seven selected quality of life indicators, standardized values, in 2015, Ward's clustering method, and squared Euclidean distances

Source: author. 
Table 5 Classification of 34 European countries according to selected quality of life indicators, standardized values, in 2015, Ward's clustering method, and squared

Euclidean distances

\begin{tabular}{|c|c|c|}
\hline $\begin{array}{c}\text { Cluster A - old EU } \\
\text { members ( } 13 \text { countries) }\end{array}$ & $\begin{array}{c}\text { Cluster B - new EU members } \\
\text { (13 countries) }\end{array}$ & $\begin{array}{c}\text { Cluster } \mathrm{C} \text { - other countries } \\
\text { (8 countries) }\end{array}$ \\
\hline $\begin{array}{l}\text { Austria, Belgium, Denmark, } \\
\text { Finland, France, Germany, } \\
\text { Ireland, Italy, Netherlands, } \\
\text { Norway*, Sweden, } \\
\text { Switzerland*, United } \\
\text { Kingdom }\end{array}$ & $\begin{array}{l}\text { Bulgaria, Croatia, Czech } \\
\text { Republic, Estonia, Greece*, } \\
\text { Hungary, Latvia, Lithuania, } \\
\text { Poland, Portugal*, Slovakia, } \\
\text { Slovenia, Spain* }\end{array}$ & $\begin{array}{l}\text { Belarus, Bosnia and } \\
\text { Herzegovina, FYROM, } \\
\text { Moldova, Romania*, } \\
\text { Russia, Serbia, Ukraine }\end{array}$ \\
\hline
\end{tabular}

Notice: with * are marked countries which, according to defined classification of countries in Chapter 2, should be in another cluster.

Source: author.

If the linkage distances are observed, according to the dendrogram in Figure 2, three main clusters can be recognized. Furthermore, the solution with three clusters is chosen because of an intuitive interpretation of clusters. In that way differences between clusters with high quality of life level countries, medium quality of life level countries, and low quality of life level countries are recognised. However, it is not known which cluster contains countries with the highest quality of life level, and which one with the lowest quality of life. Because of that, the quality of life indicators means for countries in each cluster are calculated, as shown in Table 6.

Table 6 Means of selected quality of life indicators for countries in each cluster, unstandardized data, in 2015

\begin{tabular}{|l|r|c|c|c|c|c|}
\hline \multirow{2}{*}{\multicolumn{1}{|c|}{ Variable / Indicator }} & \multicolumn{2}{|c|}{ Cluster A } & \multicolumn{2}{c|}{ Cluster B } & \multicolumn{2}{c|}{ Cluster C } \\
\cline { 2 - 7 } & Mean & Rank & Mean & Rank & Mean & Rank \\
\hline Purchasing Power Index & 102.39 & 1 & 55.27 & 2 & 35.78 & 3 \\
Safety Index & 63.40 & 2 & 64.96 & 1 & 58.01 & 3 \\
Health Care Index & 72.12 & 1 & 62.29 & 2 & 47.76 & 3 \\
Consumer Price Index & 92.27 & 3 & 55.73 & 2 & 44.19 & 1 \\
Property Price to Income Ratio & 7.79 & 1 & 10.39 & 2 & 15.27 & 3 \\
Traffic Commute Time Index & 29.93 & 2 & 29.04 & 1 & 31.98 & 3 \\
Pollution Index & 32.79 & 1 & 40.62 & 2 & 61.62 & 3 \\
\hline
\end{tabular}

Source: author.

The three separated clusters of countries are labelled as clusters A, B and C. If the clusters means are observed, countries in cluster A are, according to quality of life level, ranked on the first place at four observed quality of life indicators. The countries in cluster A have in average the highest consumer prices (according to Consumer Price Index). Also, these countries have a little bit less safer environment and a little bit longer average commuting one way time than the countries in cluster B (according to Traffic Commute Time Index). Nevertheless, in general, it could be concluded that countries in cluster A have the highest quality of life level in compare to countries in other two clusters. From 13 countries in this cluster, there are 11 old European Union member states whereas two countries are not the European Union members. Because of that, it has been concluded that this cluster is representing old European Union member states, and so, it will be observed in the further analysis.

If the Traffic Commute Time Index is observed, it can be concluded that countries in cluster B have the lowest average commuting one-way time. Furthermore, the safety level in average is the highest in countries that are in cluster B. At all other observed quality of life indicators, countries in cluster B are placed on the second 
place. Consequently, it can be concluded that countries in cluster $B$ have medium quality of life level. Cluster B is consisted, in vast majority, of 10 the new European Union member states. In Cluster B there are three old European Union member states also. Consequently, this cluster is going to represent this group of countries in the further analysis.

Obviously, countries in cluster $C$ have the lowest quality of life level in comparison to countries in previous two clusters. The only thing, which is positive in countries in

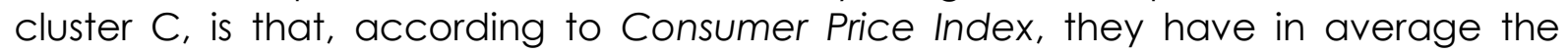
lowest consumer prices. The cluster $C$ includes seven countries, which are not the European Union member states, and one country, which is the new European Union member state. Because of that, it has been decided that this cluster is going to represent the group of countries, which are not European Union member states (yet).

According to conducted ranking, which is provided in Table 6 , it can be concluded that the old European Union member states have in average higher quality of live level than the new European Union member states. Furthermore, it can be said that the European Union member states have in average higher quality of live level than non-European Union member states is true statement. Regarding given results it can be concluded that both research hypotheses could be accepted. However, in order to make conclusions, some additional analyses must be conducted and presented in the following chapter.

\section{Comparison of attained quality of life level between clusters of countries}

The conducted statistical hierarchical cluster analysis grouped countries into the clusters and enabled making some initial ranking of countries according to their quality of life level. In order to determine if there are statistically significant differences for given average values of identified clusters, the ANOVA analysis was conducted (Table 7).

Table 7 One-way analysis of variance based on clusters means of selected quality of life indicators, degrees of freedom for numerator 2 and for denominator 31

\begin{tabular}{|l|r|c|c|r|r|}
\hline \multirow{2}{*}{\multicolumn{1}{|c|}{ Variable / Indicator }} & \multicolumn{3}{|c|}{ Means } & \multirow{2}{*}{ F-ratio } & p-value \\
\cline { 2 - 4 } & Cluster A & Cluster B & Cluster C & & \\
\hline Purchasing Power Index & 102.39 & 55.27 & 35.78 & 83.649 & 0.0000 \\
Safety Index & 63.40 & 64.96 & 58.01 & 2.098 & 0.1398 \\
Health Care Index & 72.12 & 62.29 & 47.76 & 24.990 & 0.0000 \\
Consumer Price Index & 92.27 & 55.73 & 44.19 & 55.318 & 0.0000 \\
Property Price to Income Ratio & 7.79 & 10.39 & 15.27 & 41.877 & 0.0000 \\
Traffic Commute Time Index & 29.93 & 29.04 & 31.98 & 0.735 & 0.4877 \\
Pollution Index & 32.79 & 40.62 & 61.62 & 13.266 & 0.0000 \\
\hline
\end{tabular}

Source: author.

In one-way analysis of variance tests under the null hypothesis it is assumed that all sample means are equal whereas under the alternative hypothesis it is assumed that there is at least one sample mean which is statistically significant different than the others (Field, 2009). Under the null hypothesis here, it is assumed that all cluster means are equal observing each quality of life indicator separately.

According to the results of one-way analysis of variance, at significance level of $5 \%$, it can be concluded that there is no statistically significant difference in means between clusters when the Safety Index and the Traffic Commute Time Index respectively are observed. At all other quality of life indicators, at significance level 
of $5 \%$, there is at least one cluster mean, which is significantly different than are the other means.

The conducted one-way analysis of variance has shown statistically significant differences in quality of life level at five from seven quality of life indicators. The problem is that the one-way analysis of variance cannot show which means are different. Consequently, the clusters cannot be ranked according to their quality of life level. Because of that additionally have $95 \%$ confidence intervals for means for each cluster and observed quality of life indicators constructed and shown in Table 8.

Table 8 Confidence intervals for means for selected quality of life indicators in European countries grouped into the three clusters, confidence level 95\%, in 2015

\begin{tabular}{|l|r|r|r|r|r|r|}
\hline \multirow{2}{*}{ Variable / Indicator } & \multicolumn{2}{c|}{ Cluster A } & \multicolumn{2}{c|}{ Cluster B } & \multicolumn{2}{c|}{ Cluster C } \\
\cline { 2 - 7 } & $\begin{array}{c}\text { Lower } \\
\text { limit }\end{array}$ & $\begin{array}{c}\text { Upper } \\
\text { limit }\end{array}$ & $\begin{array}{c}\text { Lower } \\
\text { limit }\end{array}$ & $\begin{array}{c}\text { Upper } \\
\text { limit }\end{array}$ & $\begin{array}{c}\text { Lower } \\
\text { limit }\end{array}$ & $\begin{array}{c}\text { Upper } \\
\text { limit }\end{array}$ \\
\hline Purchasing Power Index & 95.37 & 109.41 & 48.25 & 62.29 & 26.83 & 44.73 \\
Safety Index & 59.05 & 67.75 & 60.60 & 69.31 & 52.46 & 63.56 \\
Health Care Index & 67.78 & 76.46 & 57.95 & 66.63 & 42.22 & 53.29 \\
Consumer Price Index & 85.88 & 98.66 & 49.34 & 62.12 & 36.04 & 52.33 \\
Property Price to Income & 6.76 & 8.82 & 9.36 & 11.42 & 13.96 & 16.58 \\
Ratio & 26.85 & 33.00 & 25.96 & 32.11 & 28.06 & 35.90 \\
Traffic Commute Time Index & 25.68 & 39.91 & 33.51 & 47.74 & 52.55 & 70.69 \\
Pollution Index
\end{tabular}

Source: author.

The calculated $95 \%$ confidence intervals for clusters means are mutually compared. If the $95 \%$ confidence intervals for cluster means at certain variable are overlapping, it has been concluded that there is no statistically significant difference in means between these clusters at that variable. The one-way analysis of variance results are confirmed by overlapping means of all three clusters at the Safety Index and the Traffic Commute Time Index. The $95 \%$ confidence intervals for clusters means are not overlapped at the Purchasing Power Index, the Health Care Index, and the Property Price to Income Ratio. At the Consumer Price Index, $95 \%$ confidence intervals of means at clusters B and C are overlapped, whereas at the Pollution Index 95\% confidence intervals of means at clusters A and B are overlapped.

In order to make final conclusion about the first research hypothesis $95 \%$ confidence intervals of means at clusters $A$, in which are the old European Union member states, and $B$, in which are the new European Union member states, are compared. At the Safety Index, the Traffic Commute Time Index, and the Pollution Index $95 \%$ confidence intervals of means at clusters A and B are overlapped. These results suggest that there is no statistically significant difference in quality of life level when those quality of life indicators are observed. At the Purchasing Power Index, the Health Care Index, and the Property Price to Income the $95 \%$ confidence intervals of means have shown statistically significant higher quality of life level in cluster $A$ in compare to the cluster B. On the other hand, the $95 \%$ confidence intervals of means at the Consumer Price Index favours more cluster B than cluster A. All in overall, it can be concluded that the old European Union member states have in average higher quality of live level than the new European Union member states. In other words, the first research hypothesis has been accepted.

The second research hypothesis is going to be inspected by comparing $95 \%$ confidence intervals of means of clusters $A$ and $B$, in which there are European Union member states, with cluster $C$, which represents non-European Union member states. 
Like before, it was seen, at the Safety Index and the Traffic Commute Time Index $95 \%$ confidence intervals of means of all clusters are overlapping. Therefore, there is no statistically significant difference in quality of life levels in European Union member states and non-European Union member states if only those two quality of life indicators are observed. The Consumer Price Index $95 \%$ confidence intervals of means show that the quality of life level is higher in non-European Union member states than in European Union member states. However, the remaining quality of life indicators show that the quality of life level is higher in European Union member states than in non-European Union member states. Consequently, the second research hypothesis is accepted, which means that the European Union member states have in average higher quality of live level than non-European Union member states.

\section{Conclusions}

From their beginnings, people are striving to achieve higher quality of life level. Unfortunately, the differences in quality of life levels are dramatically high when countries around the Globe are compared. It is not necessary to make global comparison to see the huge differences. The problem of unequal quality of life level is also obvious when only European countries are observed.

The quality of life level could be measured by using different data and different analysis approaches: firstly, by using many different variables in order to group them and get meaningful units, and then making conclusions about the achieved quality of life levels, and secondly, by using of parsimony approach, with carefully selected variables, which can successfully describe the quality of life in a country, too.

In this paper, the second approach was applied and therefore seven quality of life indicators were used to determine quality of life levels in 34 European countries. These research settings are different from previous research, and, because of that, direct comparison of results is not possible. Using hierarchical cluster analysis three clusters of countries were recognized: the old European Union member states, the new European Union member states, and the non-European Union member states. Conducted one-way analysis of variance and confidence intervals of mean have shown that in average the highest quality of life level is in the old European Union member states. On the other hand, in average the lowest quality of life level came out to be in non-European Union member states.

In this paper, only selected 34 European countries were observed. Because of that in further research, all European countries should be included in the analysis. Another limitation of the research is that only data for 2015 are used. In order to get better insight into the quality of life levels, it is recommended to observe theirs developments in European countries through the time for, at least, ten consecutive years. The main limitation of the paper is the restricted selection of the quality of life indicators. The subjective quality of life indicators should be taken into account in the further research, too.

\section{References}

1. Constanza, R., et al. (2007). Quality of life: An approach integrating opportunities, human needs, and subjective well-being. Ecological Economics, Vol. 61, pp. 267-276.

2. Diener, E., Suh, E. (1997). Measuring quality of life: economic, social, and subjective indicators. Social Indicators Research, Vol. 40, pp. 189-216.

3. Economist Intelligence Unit (2004). The Economist Intelligence Unit's quality-of-life index. Available at http://www.economist.com/media/pdf/QUALITY_OF_LIFE.pdf [8 October 2015]. 
4. European Commission (2015). Conditions for membership. Available at http://ec.europa.eu/enlargement/policy/conditions-membership/index_en.htm [12 October 2015].

5. Eurostat (2015). Quality of life indicators. Available at http://ec.europa.eu/eurostat/statistics-explained/index.php/Quality_of_life_indicators [8 October 2015].

6. Everitt, B. S., Landau, S., Leese, M. (2001). Cluster Analysis. Arnold, London.

7. Field, A. (2009). Discovering statistics using SPSS. Sage, Thousand Oaks.

8. Georgiu, J., Hancock, P. (2009). Quality of Life Indicators: The Objective-Subjective Interrelationship That Exists within One's 'Place of Residence' in Old Age. Asian Social Science, Vol. 5, pp. 3-20.

9. Greenwood, D. (2001). Local indicators of quality of life: A Preliminary Look at the Pikes Peak Region. Working paper no. 6, Center for Colorado Policy Studies. Available at http://www.uccs.edu/Documents/ccps/qol.pdf [8 October 2015].

10.Grein, A. F., Sethi, S. P., Tatum, L. G. (2010). A Dynamic Analysis of Country Clusters, the Role of Corruption, and Implications for Global Firms. East-West Journal of Economics and Business, Vol. 13, pp. 33.60.

11. Hayashi, $H_{\text {., }}$ et al. (2011). Cluster analysis revealed differences on quality of life and susceptibility to exacerbation between subpopulations of smokers including COPD. European Respiratory Journal, Vol. 38.

12. Hirschberg, J. G., Maasoumi, E., Slottje, D. J. (1991). Cluster analysis for measuring welfare and quality of life across countries. Journal of Econometrics, Vol. 50, pp. 131-150.

13. Hirschberg, J. G., Maasoumi, E., Slottje, D. J. (2001). Clusters of attributes and well-being in the USA. Journal of Applied Econometrics, Vol. 16, pp. 445-460.

14.Insee, F. (2010). Objective Indicators of Quality of life. Available at http://www.nsi.bg/sites/default/files/files/pages/dgins/dgins_papers/Insee\%20paper\%20 Objective\%20Indicators\%20of\%20Quality\%20of\%20life.pdf [24 November 2015].

15. Jain, A. K. (2010). Data clustering: 50 years beyond K-means. Pattern Recognition Letters, Vol. 31, pp. 651-666.

16.Krupka, J., Provazníkova, R., Langer, J., Kašparova, M. (2013). Standards of Living Indices Modelling in European Monetary Union Members Countries. In Proceedings of the 2013 International Conference on Economics and Business Administration, Long, C. A., Mastorakis, N. E., Mladenov, V. (Eds.), Rhodes Island, Greece, July 16-19, 2013, pp. 129136. Available at http://www.inase.org/library/2013/rhodes/EBA.pdf [25 November 2015].

17.Nagel, G. C., Schmidt, S., Strauss, B. M., Katenkamp, D. (2001). Quality of life in breast cancer patients: a cluster analytic approach. Breast Cancer Research and Treatment, Vol. 68, pp. 75-87.

18.Noll, H. H. (2004). Social Indicators and Quality of Life Research: Background, Achievements and Current Trends. In Advances in Sociological Knowledge over Half a Century, Genov, N. (Ed.), Springer, Wiesbaden, pp. 151-181.

19. Numbeo (2015a). About Cost of Living Indices At This Website. Available at http://www.numbeo.com/cost-of-living/cpi_explained.jsp [6 October 2015].

20.Numbeo (2015b). About Crime Indices At This Website. Available at http://www.numbeo.com/crime/indices_explained.jsp [6 October 2015].

21.Numbeo (2015c). About Health Care Indices At This Website. Available at http://www.numbeo.com/health-care/indices_explained.jsp [6 October 2015].

22. Numbeo (2015d). About Pollution Indices At This Website. Available at http://www.numbeo.com/pollution/indices_explained.jsp [6 October 2015].

23. Numbeo (2015e). About Property Value and Investment Indicators at This Website. Available at http://www.numbeo.com/property-investment/indicators_explained.jsp [6 October 2015].

24.Numbeo (2015f). About Traffic Indices At This Website. Available at http://www.numbeo.com/traffic/indices_explained.jsp [6 October 2015].

25.Numbeo (2015g). Europe: Quality of Life Index by Country 2015. Available at http://www.numbeo.com/quality-of-life/rankings_by_country.jsp?title $=2015 \&$ region $=150$ [6 October 2015]. 
26.OECD (2011). Compendium of OECD well-being indicators. Available at http://www.oecd.org/std/47917288.pdf [8 October 2015].

27.Pakran, J., Riyaz, N., Nandakumar, G. (2011). Determinants of quality of life in psoriasis patients: A cluster analysis of 50 patients. Indian Journal of Dermatology, Vol. 56, pp. 689693.

28.Smedt, M. (2015). Social Reporting of the European Union - Description of the Organization. In Global Handbook of Quality of Life: Exploration of Well-Being of Nations and Continents, Glatzer, W., Camfield, L., Møller, V., Rojas, M. (Eds.), Springer, Dordrecht, pp. 771-785.

29.Tonon, G. (Ed.) (2015). Qualitative Studies in Quality of Life: Methodology and Practice. Springer, Cham.

30.Toshkov, D., Kortenska, E., Dimitrova, A., Fagan, A. (2014). The "Old" and the "New" Europeans: Analyses of Public Opinion on EU Enlargement in Review. MAXCAP Working Paper Series, No. 02, Freie Universität, Berlin.

\section{About the author}

Berislav Žmuk, PhD, graduated at the major Accounting, post-graduated Statistical Methods for Economic Analysis and Forecasting, and gained his PhD degree in Business Economics at Faculty of Economics and Business, University of Zagreb. Currently he is a Senior Assistant at the Department of Statistics, Faculty of Economics and Business, University of Zagreb where he teaches following subjects: Statistics, Business Statistics and Business Forecasting. In 2013, he successfully completed Sampling Program for Survey Statisticians (SPSS) at Survey Research Center (SRC), Institute for Social Research (ISR), University of Michigan in Ann Arbor, Michigan, USA. In 2015, he completed several survey methodology courses (Introduction to Web Surveys, Introduction to Questionnaire Design, Mixed-Mode and Mixed-Device Surveys) at Gesis, Leibniz Institute for Social Research in Cologne, Germany. His main research fields include applications of statistics in business and economy, survey methodology and statistical quality control. The author can be contacted at bzmuk@efzg.hr. 